\title{
О НЕКОТОРЫХ ПРОБЛЕМНЫХ АСПЕКТАХ НАСЛЕДОВАНИЯ ЗЕМЕЛЬНЫХ УЧАСТКОВ И СПОСОБАХ ИХ РАЗРЕШЕНИЯ В СУДАХ
}

\section{ON SOME PROBLEM ASPECTS OF LAND INHERITANCE AND WAYS OF THEIR RESOLUTION IN COURTS}

A. Gudkov

A. Krasilschikov V. Mishchenko

Summary. In this article, the authors consider the features of the inheritance of land plots, the conditions under which the right of inheritance can be realized, analyze some problematic aspects of inheritance and conflicts in law. The authors also analyze the reasons for disputes over the inheritance of land plots and how they are resolved in courts.

Keywords: inheritance, circle of heirs, land plots, litigation.
Гудков Анатолий Иванович К.ю.н., дочент, ВЮИ ФСИН России gudkovaniv@yandex.ru Красильщиков Анатолий Владимирович К.ю.н., дочент, ВЮИ ФСИН России krasilschikov@inbox.ru

Мищенко Вячеслав Иванович К.ф.н., дочент, ВЮИ ФСИН России vyacheslav-mischenko@mail.ru

Аннотация. В данной статье авторы рассматривают особенности наследования земельных участков, условия, при соблюдении которых может быть реализовано право наследования, анализируют некоторые проблемные аспекты вступления в наследство и коллизии в праве. Авторы также анализируют причины споров по вопросу наследования земельных участков и способы их решения в судах.

Ключевые слова: наследство, круг наследников, земельные участки, судебные споры.
3. Участок не должен находиться в судебном споре или в собственности лица, в отношении которого возбуждено арбитражное дело о банкротстве.

4. Земельный участок должен иметь характеристики, позволяющие установить его точное месторасположение и границы.

При этом необходимо учитывать, что существуют определенные ограничения прав на вступление в наследство, установленные в силу закона или судебного акта.

Наследованию подлежат земельные участки, свободные от застройки, либо на которых возведены капитальные строения или сооружения. При этом наследник вступит в наследство на земельный участок, находящийся под строением, в том случае, если здание также принадлежало наследодателю. Если же собственником недвижимости является иное лицо, такое наследование запрещено, а свидетельство о наследстве, выданное на такой земельный участок, будет являться недействительными. Таким образом, владение недвижимостью является первичным правом и не допуска- 
ет наличие иного владельца земли. Свободный от застройки земельный участок должен подтверждаться кадастровой съемкой, выполненной на момент вступления лиц в наследство.

Следует отметить, что некоторые субъекты ограничены в правах при принятии наследства. В частности, эти ограничения могут быть установлены наследственным договором, а также исходить из особенностей целевого назначения земельного участка. Например, земли сельскохозяйственного назначения должны быть отчуждены после наследования, если наследниками являются иностранные юридические или физические лица, лица без гражданства, а также организации, имеющие в уставном капитале более 50\% доли иностранных субъектов [4].

Наследственным договором, заключенным между наследодателем или наследниками, могут устанавливаться условия и обязательства сторон, при соблюдении которых может быть реализовано право наследования. В противном случае лицо не сможет вступить в наследство. Наследственный договор является обязательным для всех его подписантов, даже если один из них отказался от наследства. При жизни наследодателя данный договор может быть оспорен иными наследниками, права которых нарушены. В частности, лица, имеющие право на обязательную долю в наследстве, могут потребовать отмены такого договора, если нарушены или не учтены их права.

Вступающие в наследство на земельный участок лица вправе разделить его, установив доли соразмерно требованиям закона или завещания, если данный участок подлежит разделу [3]. Как правило, нотариус не компетентен в этой области, поэтому наследники заинтересованы в добровольном разделении долей и согласовании плана раздела. В противном случае судебные споры по разделу земельного участка могут препятствовать вступлению в наследство. В случае невозможности раздела право наследования на участок приобретает наследник, имеющий приоритетное право на наследство. А в случае его отказа от первоочередного права наследования в наследство могут вступить иные наследники. Лица, которые в результате раздела участка не получили прав на землю вследствие его неделимости, имеют право на денежную компенсацию своей доли в наследстве.

В отличие от права собственности, право наследодателя на пожизненное наследуемое владение должно быть зарегистрировано в ЕГРН. Основанием возникновения такого права является решение органа, в ведении которого находится земельный участок государственной или муниципальной собственности. Право пожизненного наследуемого владения на землю может возникать как у граждан, так и у юридических лиц независимо от формы собственности [2]. Если на таком участке в дальнейшем будет зарегистрировано право собственности на недвижимость, то его наследник вправе заключить договор аренды земельного участка либо выкупить его в установленном порядке.

Завещанием или совместным завещанием супругов может быть ограничен круг лиц, имеющих право на наследство, а также установлена очередность наследования. Стоит отметить, что в отличие от совместного завещания супругов, наследование земли по наследственному договору с несколькими наследодателями будет невозможным, если ко дню вступления наследства один из наследодателей по договору окажется умершим.

Нередко судебные споры возникают на этапе вступления лиц в наследство по причинам:

1. пропуска срока для вступления в наследство;

2. отсутствия зарегистрированного в реестре права собственности на земельный участок;

3. оспаривания завещания или наследственного договора;

4. ограничения прав на земельный участок, в том числе наложенного по исполнительному документу;

5. оспаривания документов - оснований для выдачи прав на землю;

6. невозможности передачи земельного участка;

7. отказом нотариуса выдать свидетельство о наследстве на земельный участок;

8. нарушения прав одного из наследников.

Наследник, оспаривающий вступление в наследство других лиц, вправе обратиться с гражданским иском в суд по месту нахождения земельного участка и обосновать нарушение его права. Зачастую споры между наследниками возникают с умыслом затянуть процесс вступления в наследство, а доводы иска не всегда подтверждены необходимыми доказательствами. В частности, достаточными доказательствами для оспаривания свидетельства о наследстве по завещанию будет нотариальный наследственный договор, заключенный после удостоверения завещания либо новое завещание, в том числе совместное завещание супругов. В некоторых случаях заявителями в суде выступают кредиторы по делу о банкротстве наследодателя, которые в силу закона имеют право на взыскание долга с наследников. В этом случае наследственный договор утрачивает силу, а кредиторы имеют преимущественное право требования, даже если земельный участок не был своевременно включен в наследственную массу [5]. 
Что касается пожизненного наследуемого владения, то кредиторы не вправе оспорить выданное нотариусом свидетельство о наследстве на земельный участок, так как, несмотря на право владение наследодателя, недвижимое имущество является собственностью иных лиц. Из этого можно заключить, что право аренды на земельный участок или право пожизненного наследуемого владения - наиболее безопасный способ владения земельным участком, так как его невозможно отчуждать, кроме как по праву наследования.

В некоторых случаях наследники сталкиваются с невозможностью принятия наследства вследствие не установления границ земельного участка наследодателем, отсутствия необходимых данных о нем в кадастровой выписке или наличия ошибок в документах о правах на землю (несовпадение кадастрового номера, площади, адреса или целевого назначения земельного участка). В частности, наследодатели могли заключить наследственный договор на земельный участок, который был в последствии разделен и кадастровые изменения внесены в единый реестр, либо изменен правовой режим земель, либо уточнены данные о земельном участке касаемо его места расположения или площади. В этом случае нотариус правомерно откажет в оформлении наследства по наследственному договору и выдаст свидетельства о наследстве по закону.

Наследственные споры по земельным участкам также возникают при установлении его границ, в частности с соседями участков. Нередко оказывается, что границы смежных участков нарушены либо затрагивают общие зоны владения (сервитуты). В этом случае наследники смогут вступить в наследство только после уточнения границ земельного участка и установить права в порядке судебного спора. Несовпадение характеристик правоустанавливающего документа на землю и выписки из ЕГРН также приведет к отказу нотариуса в совершении нотариальных действий.

Право собственности на земельный участок подтверждается свидетельством о праве собственности, зарегистрированным в Едином государственном реестре недвижимости (ЕГРН). На практике нередки случаи, когда наследодатель не обладал достаточным основанием для подтверждения права собственности на земельный участок, например, при жизни не успел зарегистрировать право собственности по договору дарения или купли-продажи. В таком случае наследники имеют право обратиться с иском к продавцам и признании за ними права собственности на земельный участок в порядке наследования.

Нотариус вправе отказать наследникам в выдаче свидетельства о наследстве на землю вследствие его никчемности, если завещание не соответствует требованиям закона или составлено с нарушением либо подписано недееспособным лицом, а также лицом, не обладающим достаточными полномочиями. В этом случае наследники вправе оспорить отказ нотариуса по месту его нахождения. В свою очередь, иски о признании завещания или наследственного договора недействительными могут предъявляться по месту открытия наследства [5].

Кроме того, законодательством ограничен срок для вступления наследства - шесть месяцев со дня открытия наследства. Если наследник не подал нотариусу заявление о вступлении в наследство, срок будет упущен и за его восстановлением необходимо обратиться в суд, либо признать факт вступления в наследство в судебном порядке. Одновременно с этим необходимо учитывать правила подсудности некоторых исков, связанных с вступлением в наследство.

В отличие от исков о праве на наследство, которые В порядке ст. 30 ГПК РФ [1] подаются по месту нахождения наследуемого участка, и исков об оспаривании завещания, которые подаются в порядке ст. 28 ГПК РФ по месту нахождения ответчика, иски по установлению факта принятия наследства на земельный участок подаются наследником по месту его жительства в порядке ст. 266 ГПК РФ. В свою очередь, иски о признании факта владения и пользования земельным участком подаются по месту нахождения имущества. При этом Верховный Суд РФ [5] разъяснил, что при восстановлении срока на вступление в наследство или признания факта наследования отсутствие обращения наследника к нотариусу не является препятствием для принятия иска судом, так как подача заявления нотариусу - это право наследника, а него его обязанность. Наличие судебного спора по наследованию земельного участка позволяет истцу по его ходатайству в судебном порядке приостановить вступление в наследство у нотариуса до принятия судом решения по существу.

В целом, споры наследников о праве наследство имеют разную правовую природу, поэтому способ защиты права должен соответствовать проблематике вопроса. В противном случае наследник может потерять срок для обращения в суд и получить отказ в удовлетворении иска.

Вместе с тем, следует отметить неурегулированность законодательства по вопросам установления прав на наследство при оспаривании свидетельства о наследстве иностранными гражданами и лицами без гражданства, которые имеют право на наследство по закону или завещанию. В частности, иск об установлении факта вступления в наследство подается 
по месту жительства наследника, а доказывание факта пользования земельным участком требует наличия у иностранного субъекта права на временное проживание в РФ. В этом случае устанавливать факт сложнее, так как, во-первых, иностранец может быть не уведомленным об открытии наследства, а во-вторых, право владения не может быть признано судом, если иностранный субъект не посещал РФ последние три года.

\section{ЛИТЕРАТУРА}

1. Гражданский кодекс Российской Федерации (часть третья) от 26.11.2001 N146-Ф3 (ред. от 18.03.2019) // Собрание законодательства РФ. 03.12 .2001$. N49. ст. 4552.

2. Земельный кодекс Российской Федерации» от 25.10.2001 N136-Ф3 (ред. от 02.07.2021) (с изм. и доп., вступ. в силу с 01.09.2021) // СПС Консультант Плюс. Дата обращения 12.11.2021 года.

3. Градостроительный кодекс Российской Федерации» от 29.12.2004 N190-Ф3 (ред. от 02.07.2021) (с изм. и доп., вступ. в силу с 01.10.2021) // СПС Консультант Плюс. Дата обращения 12.11.2021 года.

4. Федеральный Закон «0б обороте земель сельскохозяйственного назначения» от 24.07. 2002 № 101-ФЗ// СПС Консультант Плюс. Дата обращения 12.11.2021 года.

5. Постановление Пленума Верховного Суда РФ № 9 от 29.05.2012 г.

6. Корчагина Н.В. «Наследование земельных участков: особенности и спорные вопросы». Юридические науки. № 6 (8). 2016.

(с Гудков Анатолий Иванович ( gudkovaniv@yandex.ru ),

Красильщиков Анатолий Владимирович ( krasilschikov@inbox.ru ), Мищенко Вячеслав Иванович ( vyacheslav-mischenko@mail.ru ).

Журнал «Современная наука: актуальные проблемы теории и практики»

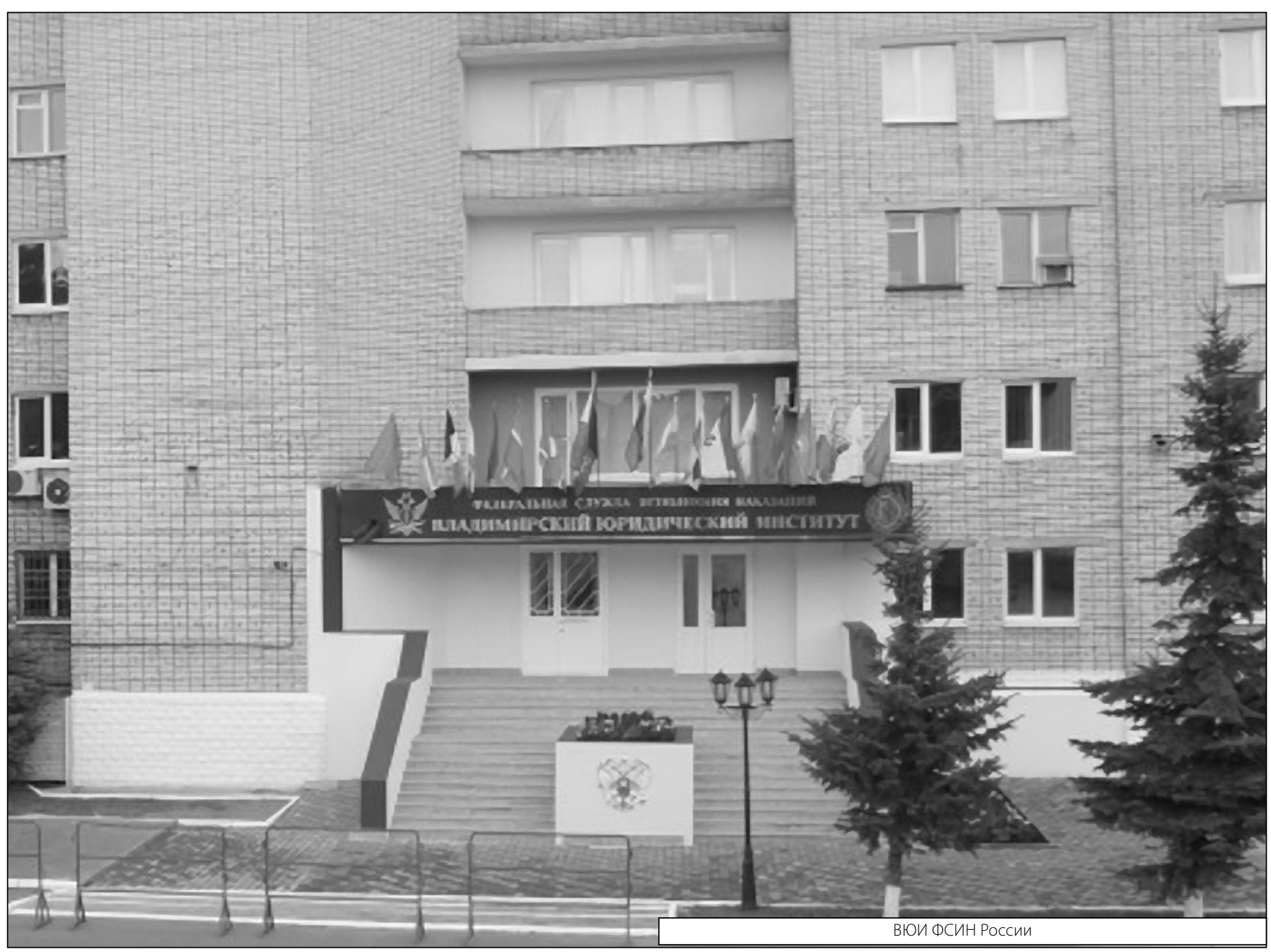

